УДК 332.012.2

DOI: https://doi.org/10.37320/2415-3583/12.19

Злотнік М.Л.

аспірантка кафедри зовнішньоекономічної та митної діяльності, Національний університет «Львівська політехніка» ORCID: http://orcid.org/0000-0002-4313-6771

Мельник О.Г. доктор економічних наук, професор, завідувачка кафедри зовнішньоекономічної та митної діяльності, Національний університет «Львівська політехніка» ORCID: http://orcid.org/0000-0001-8819-1910

\title{
СТРАТЕГІЧНЕ УПРАВЛІННЯ ВПРОВАДЖЕННЯМ ПРИНЦИПІВ ЦИРКУЛЯРНОЇ ЕКОНОМІКИ НА ВІТЧИЗНЯНИХ ПІДПРИЕМСТВАХ
}

У статті проаналізовано та згруповано підходи вітчизняних та зарубіжних науковців до визначення поняття «циркулярна економіка», основних ї̈ положень та застосування на рівні стратегічного управління підприємством. Запропоновано власне трактування иьього поняття. Виконано порівняльний аналіз ключових принципів лінійної та ичиркулярної економіки. Розглянуто основні стратегї та бізнес-моделі в межах ичркулярної економіки, охарактеризовано переваги їх впровадження. Ідентифіковано перешкоди для стратегічного управління підприємствами в умовах циикулярної економіки. Визначено особливості стратегічного управління в умовах ицикулярної економіки, охарактеризовано окремі корпоративні та виробничі стратегії в межсах ичиркулярної економіки, виокремлено основні вимоги та завдання щьодо впровадження ідей циркулярної економіки на рівні стратегії.

Ключові слова: ичикулярна економіка, лінійна економіка, стратегічне управління підприємством, бізнесмодель, сталий розвиток, стратегія.

Постановка проблеми. У мінливих ринкових умовах для отримання довгострокових конкурентних переваг компанії мають враховувати нові концепції та методи управління, що грунтуються на збалансуванні унікальної цінності компанії, їі основних компетенцій, соціальної відповідальності перед власниками та кре- 
диторами, працівниками та місцевою громадою, клієнтами та природним середовищем. Особливо важливим $\epsilon$ врахування глобальних тенденцій, таких як підвищення толерантності до різних груп осіб, орієнтація на більш здоровий та екологічно приязний спосіб життя, свідоме споживання.

Стратегічне управління підприємствами також вимагає переосмислення та потребує розроблення гнучких реактивних рішень, переорієнтації стратегії не лише на розвиток самого підприємства, але й на врахування потреб стейкхолдерів та довкілля. Зважена та обгрунтована побудова системи стратегічного управління відіграє вирішальну роль у контексті становлення сталого розвитку як національного пріоритету окремих підприємств та галузей, а також економіки загалом. Стратегічний менеджмент $є$ формотворчою запорукою успіху будь-якої організації, що функціонує в непрогнозованих та ризикованих умовах зовнішнього середовища.

3 огляду на проблему вичерпності та обмеженості природних ресурсів ідея впровадження кругообігу (циркуляції) ресурсів для забезпечення стійкого економічного зростання є особливо актуальною. Ця ідея втілюється в концепції циркулярної економіки. Основна ïi сутність полягає в тому, що ресурси багаторазово повертаються для використання в наступних виробничих циклах, що сприяє збереженню та більш раціональному використанню природно-ресурсного, виробничого, фінансового та кадрового потенціалу підприємства.

Задля впровадження моделей циркулярної економіки для підприємств важливим є розроблення стратегічних управлінських рішень, які б враховували соціальну, екологічну, управлінську та економічну складові частини. Для забезпечення ефективного функціонування підприємства в умовах циркулярної економіки необхідним $є$ формування середньота довгострокової стратегій управління, які могли б забезпечити відповідну модель бізнес-процесів, у межах якої збільшується додана вартість бізнесу, підвищується рівень конкурентоспроможності, повноцінно задовольняючи очікування та потреби споживачів.

Аналіз останніх досліджень і публікацій. Протягом останніх років представники наукової спільноти виявляють значну зацікавленість до проблем циркулярної економіки. Це підтверджується великою кількістю досліджень, наукових звітів, оглядів літератури у зарубіжних виданнях. Щодо українських наукових праць, то можна стверджувати, що тема циркулярної економіки перебуває на зародковому етапі, що підтверджує актуальність дослідження.

Серед зарубіжних учених значний внесок у розвиток концепції циркулярної економіки зробили такі американські дослідники, як К. Боулдинг, У. Стахіл, М. Браунгарт, У. Макдоно [1-4]. В Україні проблематика впровадження циркулярної економіки досліджується у працях Л. Сергієнко-Бердюкової, Ю. Маковецької, Т. Омельяненко $[13 ; 17]$.

Мета статті полягає в аналізі сутності, передумов розвитку та ключових принципів циркулярної економіки на основі актуальних досліджень вітчизняних та зарубіжних авторів, характеристиці особливостей реалізації стратегічного управління підприємствами в умовах циркулярної економіки.

Виклад основного матеріалу. Звертаючись до витоків наукового осмислення цієї проблематики, маємо відзначити, що вперше поняття й концепція циркулярної економіки згадуються в науковій літературі 1960-х років.

У 1966 році американський економіст К. Боулдинг висунув теорію Землі як космічного корабля. «Земля, - стверджував автор, - перетворилася в єдиний космічний корабель, на якому немає необмежених резервуарів, тому людина повинна знайти своє місце в циклічній екологічній системі» [1].

У кінці 1980-х років зусиллями групи вчених (У. Стахілем, М. Браунгарт, У. Макдоно) була відроджена ідея функціонування економіки як замкненого кола. Ці автори також досліджували ії вплив на конкурентоспроможність компаній, економію ресурсів, створення нових робочих місць і скорочення відходів [2; 3].

Значний внесок у розвиток концепції циркулярної економіки був зроблений фондом Еллен Мак-Артур. Фонд займається дослідженнями мінімізації споживання первинної сировини й зростання обсягів використання перероблюваних ресурсів задля зниження обсягів відходів, які спрямовуються на полігони та звалища. Також фонд Еллен Мак-Артур заохочує представників бізнесу до «циркулярних» інновацій та інвестує кошти в найбільш перспективні стійкі проєкти [4].

Тлумачення поняття «циркулярна економіка» можна класифікувати за двома основними підходами, а саме ресурсо-орієнтованим (спрямованість циркулярної економіки на зміну системи розподілу та обігу ресурсів) та економіко-орієнтованим (розуміння циркулярної економіки як нової системи ринкових відносин та шляху до економічного зростання). Приклади застосування згаданих підходів різними авторами та інституціями узагальнені в табл. 1.

Отже, більшість авторів у своїх визначеннях наголошує на ефективності використання ресурсів як ключовому пріоритеті концепції циркулярної економіки. Прихильники економіко-орієнтованого підходу зосереджують свою увагу на трансформації ланцюга створення вартості та моделях переробки, повторного використання, скорочення обсягів відходів. У деяких визначеннях було акцентовано увагу на зміні підходів до споживчої поведінки загалом.

Узагальнюючи наведені трактування, поняття «циркулярна економіка» слід розуміти як модель трансформаційної економіки, яка принципово змінює системи виробництва та споживання ресурсів, діє за аналогією екосистеми, орієнтована на стійкий розвиток та створює унікальну цінність завдяки круговому обігу матеріальних та нематеріальних потоків.

У зв'язку з вичерпанням природних ресурсів та критичною екологічною ситуацією у світі принципи циркулярної економіки стали пріоритетними для більшості країн, зокрема для країн Європейського Союзу. 17 грудня 2012 року був опублікований стратегічний документ Європейської комісії, що має назву «Маніфест для ресурсоефективної Свропи», в якому зазначено, що «ЄС не має жодного вибору, окрім як перехід до ресурсозберігаючої та, в кінцевому результаті, регенеративної циркулярної економіки» [11]. Очевидно, що таке твердження актуальне також для України. 
Перехід до моделей циркулярної економіки стає неминучим у контексті стрімкого зростання чисельності населення і пов'язаних з цим значних обсягів споживання, а також збільшення техногенних впливів, зменшення запасів невідновлюваних природних ресурсів і забруднення навколишнього середовища.

Задля більш грунтовного аналізування сутності циркулярної економіки доцільно розглянути передумови іiі розвитку.

Циркулярна економіка є сучасною альтернативою наявній лінійній (розподільчій) економіці, яка грунтується на принципі «візьми, використай, викинь». Лінійна економіка передбачає звичну структуру бізнес-процесів, в межах яких на вході до виробничої системи надходять сировина та матеріали, далі відбувається їх переробка, а на виході отримується продукт, готовий до використання (рис. 1). Така модель не враховує, що часто іiі результатом $\epsilon$ шкідливі викиди в навколишнє середовище. На етапі передачі кінцевого продукту споживачам виробничий цикл завершується, адже ресурси, енергія й праця, що були використані, вже не мають жодного значення у ланцюзі вартості.

Наростаючий дефіцит сировинних та енергетичних ресурсів, волатильність цін на товарних ринках, посилене забруднення навколишнього середовища, включаючи масові викиди парникових газів і забруднення морських акваторій, що загрожують незворотними кліматичними змінами, підштовхнули бізнес, політиків, наукове співтовариство, простих громадян до переосмислення традиційної моделі економіки.
Отже, була розроблена ідея циркулярної економіки, основу якої становить ланцюжок «візьми, використай, перероби». Ця концепція виникла за аналогією кругообігу ресурсів у живій природі (біомімікрії), де жодна ланка не $є$ зайвою і знаходить своє повторне використання для користі інших істот в екосистемі. Розвиток виробничої діяльності людини змістив цей кругообіг, зробивши його більш лінійним [12].

Виконавши аналіз проблем лінійного типу виробництва та переваг циркулярної економіки, ми узагальнили основні проблеми лінійного типу економіки та їх рішення, які можуть бути реалізовані за допомогою циркулярної економіки (табл. 2).

Отже, перехід до циркулярної економіки є обгрунтованим з точки зору вирішення глобальних проблем, які загрожують незворотними наслідками.

Задля більш ретельного аналізу системи циркулярної економіки та її ключових елементів доцільно графічно проілюструвати модель іiі функціонування (рис. 2).

Як видно з рис. 2, модель функціонування циркулярної економіки має форму петлі, яку формують два цикли, а саме біологічний та технічний. Більш того, циркулярна модель передбачає чітке розмежування між біорозкладними та «міцними» компонентами виробу, що дає змогу більш ефективно «замикати» обидві частини петлі. Вироби та матеріали, виготовлені з біологічних поживних речовин, призначені для безпечного повторного введення у біосферу, тоді як довговічні матеріали (наприклад, метал і пластик) можуть стати так званими технічними поживними речовинами, «які сприяють циркуляції високої якості зі збереженням або підвищенням їх економічної цінності» [14]. У технічному циклі існує 4 етапи повторної циркуляції продуктів або їх компонентів у виробництві. Організація може впроваджувати зворотні потоки як на одному етапі, так і на всіх одночасно. Крім того, енергія, необхідна для підживлення технічних

Рисунок 1 - Модель функціонування лінійної економіки

Таблиця 1 - Трактування поняття «циркулярна економіка» за підходами різних авторів

\begin{tabular}{|c|c|c|}
\hline Підхід & Автор & Трактування поняття «циркулярна економіка» \\
\hline \multirow{3}{*}{$\begin{array}{l}\text { Ресурсо- } \\
\text { орієнтований }\end{array}$} & $\begin{array}{l}\text { Г. Гіслоп, Дж. Гілл } \\
\text { [5] }\end{array}$ & $\begin{array}{l}\text { Стратегія розвитку, яка забезпечує максимальну ефективність використання ресурсів } \\
\text { та мінімізує виробництво відходів у контексті сталого економічного та соціального } \\
\text { розвитку. }\end{array}$ \\
\hline & $\begin{array}{l}\text { Фонд Еллен } \\
\text { Мак-Артур [6] }\end{array}$ & $\begin{array}{l}\text { Економіка, якій властивий відновний і замкнутий характер. Циркулярна економіка } \\
\text { виходить за рамки прагнення до зменшення кількості відходів, сприяє технологічним, } \\
\text { організаційним та соціальним інноваціям, аби «проєктувати» використання відходів } \\
\text { від самого початку виробничого циклу. }\end{array}$ \\
\hline & $\begin{array}{l}\text { Світовий Ресурсний } \\
\text { Форум [7] }\end{array}$ & $\begin{array}{l}\text { Промислова економіка, в якій матеріальні потоки продовжують циркулювати } 3 \\
\text { високою швидкістю без потрапляння матеріалів у біосферу, якщо вони не } є \text { біологічно } \\
\text { поживними речовинами. }\end{array}$ \\
\hline \multirow{3}{*}{$\begin{array}{l}\text { Економіко- } \\
\text { орієнтований }\end{array}$} & $\begin{array}{l}\text { Ф. Жиюнь, } \\
\text { У. Найлінг [8] }\end{array}$ & $\begin{array}{l}\text { Режим економічного розвитку, який вимагає дотримання екологічних законів. } \\
\text { Фактично це екологічна економіка, яка дотримується принципів скорочення } \\
\text { використання ресурсів, повторного використання продуктів та переробки. }\end{array}$ \\
\hline & Ж. Юань [9] & $\begin{array}{l}\text { Модель економіки, що діє на основі принципів скорочення, повторного використання } \\
\text { й переробки матеріалів та енергії. Цей підхід має на меті досягнення ефективної } \\
\text { економіки під час викиду меншої кількості забруднюючих речовин, що вимагає повної } \\
\text { реформи всієї системи людської діяльності. }\end{array}$ \\
\hline & $\begin{array}{l}\text { Європейська Комісія } \\
{[10]}\end{array}$ & $\begin{array}{l}\text { Стратегія розвитку, яка тягне за собою економічне зростання без збільшення } \\
\text { споживання ресурсів, глибоко трансформує виробничі ланцюги та звички споживання, } \\
\text { а також змінює промислові системи. }\end{array}$ \\
\hline
\end{tabular}


циклів, повинна відновлюватися за своєю природою, щоби зменшити залежність ресурсів та підвищити стійкість системи (наприклад, до нафтових ударів).

Беручи до уваги особливості технічного циклу, циркулярна економіка значною мірою замінює концепцію власності на концепцію доступу та продуктивності, адже підприємства продають використання продуктів, а не їх однобічне споживання.

Варто зауважити, що система циркулярної економіки не може бути повністю замкненою, як і будь-яка система у світі. На іiі виході існує так званий відтік втрат, який має бути мінімізованим.

Варто зауважити, що циркулярну економіку часто помилково ототожнюють із переробною, хоча це найбільш вузьке трактування порівняно з іншими «замкненими» бізнес-моделями (оновлення, повторне використання, відновлення) 3 точки зору ефективності використання ресурсів та економічної ефективності [6].

Крім того, циркулярна економіка передбачає зміну підходів до бізнес-моделей, у межах яких можна проєктувати більш довговічні та легко оновлювані продукти.
Циркулярні бізнес-моделі, окрім беззаперечної користі для збереження навколишнього середовища, мають низку економічних переваг, даючи змогу підприємствам отримати додаткові джерела доходу, підвищити свою конкурентоспроможність, знайти нішеві ринки, більш раціонально розподіляти свої ресурси, покращити рівень соціальної відповідальності та лояльності споживачів, посилити корпоративну культуру та запобігти ризикам вичерпання ресурсів на всіх етапах виробничого циклу тощо.

Під час створення «циркулярної» корпоративної стратегії базовим має бути принцип "rethink", тобто переосмислення наявних стратегії та місії організації, переорієнтація на екологічно сприятливий розподіл ресурсів.

На практиці стратегічне управління в межах циркулярної економіки передбачає зміну ланцюга створення вартості та переосмислення циклу життя певних продуктів. Такі глобальні організаційні зміни можуть бути впроваджені лише в умовах обгрунтованого стратегічного управління.

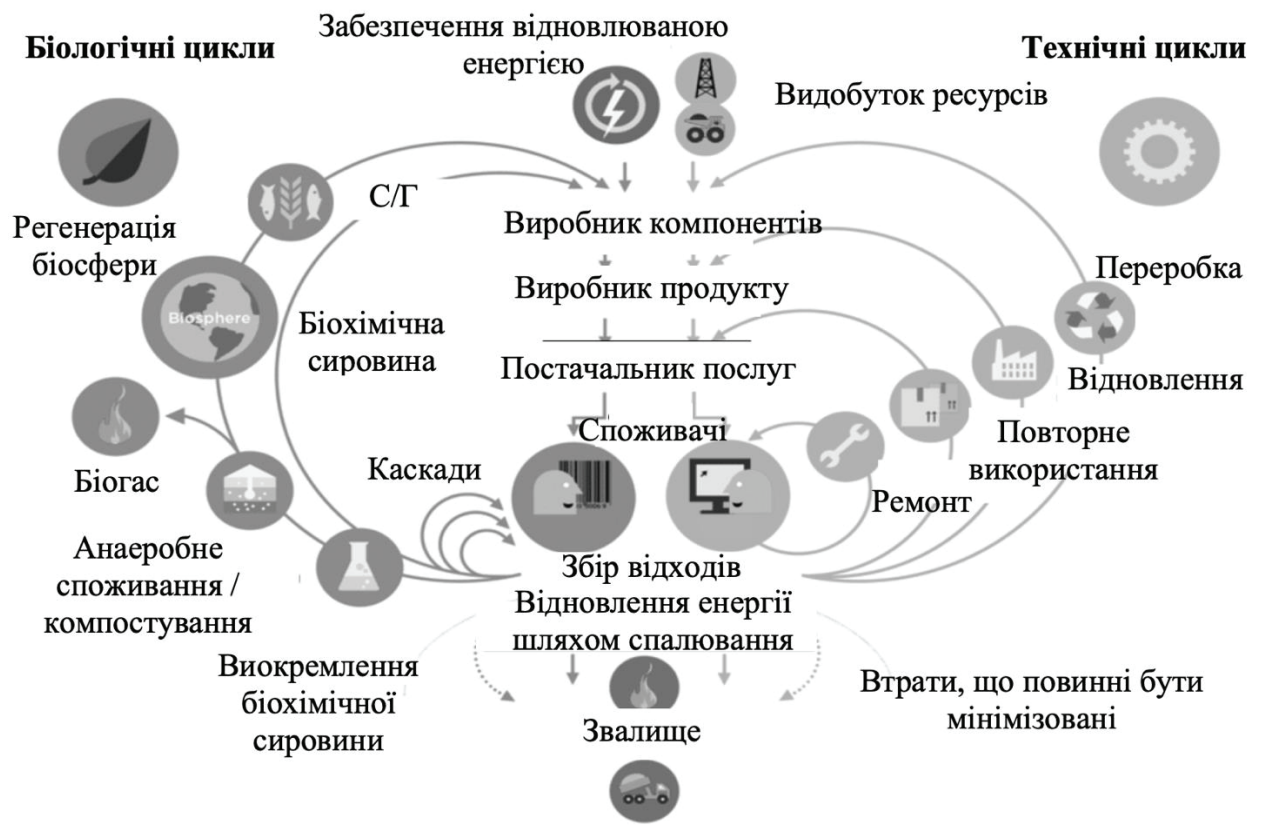

Рисунок 2 - Модель функціонування циркулярної економіки [6]

Таблиця 2 - Проблеми лінійного типу економіки та їх циркулярні рішення

\begin{tabular}{|l|l|}
\hline \multicolumn{1}{|c|}{$\begin{array}{l}\text { Проблеми, зумовлені } \\
\text { лінійною економікою }\end{array}$} & \multicolumn{1}{|c|}{ Рішення, які пропонус циркулярна економіка } \\
\hline $\begin{array}{l}\text { Нераціональне використання } \\
\text { ресурсів }\end{array}$ & $\begin{array}{l}\text { Перебудова ключових бізнес-процесів та вдосконалення ланцюга створення вартості у } \\
\text { більш стійкому напрямі. }\end{array}$ \\
\hline Вичерпання природних ресурсів & $\begin{array}{l}\text { Перехід на відновлювані матеріали та вторинну сировину, використання } \\
\text { альтернативних джерел енергії. }\end{array}$ \\
\hline $\begin{array}{l}\text { Нерівномірний розподіл та } \\
\text { споживання }\end{array}$ & $\begin{array}{l}\text { Налаштування систем зворотних потоків, впровадження послуг оренди, обміну, } \\
\text { спільного користування, пропагування ідеї свідомого споживання. }\end{array}$ \\
\hline $\begin{array}{l}\text { Погіршення загального } \\
\text { екологічного стану навколишнього } \\
\text { середовища }\end{array}$ & $\begin{array}{l}\text { Підвищення рівня екологічної відповідальності підприємств, удосконалення } \\
\text { екологічних стандартів та вимог до звітності. }\end{array}$ \\
\hline $\begin{array}{l}\text { Формування значного обсягу } \\
\text { відходів }\end{array}$ & $\begin{array}{l}\text { Скорочення рівня відходів шляхом продовження циклу життя продукту та повторного } \\
\text { використання його компонентів. }\end{array}$ \\
\hline
\end{tabular}

Джерело: сформовано авторами на основі аналізування літературних джерел [13] 
Підприємства залежно від специфіки своєї діяльності можуть ставити перед собою різні стратегічні цілі в напрямі сталого розвитку, наприклад збереження та посилення ефективності розподілу та використання ресурсів і енергії у ланцюгах виробництва, ініціювання нових ніш для бізнесу, зміна підходу до обслуговування продуктів, що використовуються повторно, трансформування продуктів у послуги, створення обмінних платформ, налагодження системи зворотної логістики.

Впровадження циркулярних бізнес-процесів у різних галузях та ланцюгах створення вартості супроводжується змінами в бізнес-середовищі. Ці зміни передбачають підвищення рівня вимог потенційних споживачів до соціальної відповідальності підприємства, «екологічності» ведення бізнесу та якісних властивостей продукції, їх впливу на навколишнє середовище.

Інтегрування принципів циркулярної економіки в корпоративну стратегію може створити довгострокову конкурентну перевагу. Задля цього доцільно дотримуватись класичного процесу стратегічного управління, що охоплює стратегічне планування, аналізування зовнішнього та внутрішнього середовищ, розроблення стратегічних альтернатив, формування й реалізацію місії та стратегії. Кожен 3 перелічених етапів має певні особливості в умовах впровадження циркулярної економіки.

Для ефективного впровадження концепції циркулярної економіки на підприємстві іiї основні принципи мають відображатись як у загальній корпоративній стратегії, так і у функціональних стратегіях. Залежно від специфіки діяльності та цілей підприємства можуть бути застосовані різні види «циркулярних» стратегій.

На рис. 3 наведено три основні стратегії впровадження циркулярної економіки, які можуть впроваджуватись підприємствами залежно від особливостей їх діяльності.

Можна підсумувати, що стратегія «замкнення циклу» спрямована на оптимізацію виробничих процесів, стратегія віртуалізації орієнтована на зниження використання ресурсів та заміну деяких продуктів на віртуальні, а стратегія обміну націлена на зміну підходів до споживання деяких продуктів та перехід на ідеї спільного використання.

Варто зауважити, що під час стратегічного управління підприємством в умовах глобальних тенденцій ресурсо- та енергоефективності, циркулярної економіки та сталого розвитку виникають певні перешкоди. У табл. 5 узагальнено основні проблеми, які постають

Загальнокорпоративні стратегії впровадження циркулярної економіки у діяльність підприємства

\begin{tabular}{|c|c|c|}
\hline «Замкнення» циклу & Віртуалізація & Обмін \\
\hline $\begin{array}{c}\text { Встановлення } \\
\text { зворотних потоків } \\
\text { для продуктів в } \\
\text { кінці їх циклу життя }\end{array}$ & $\begin{array}{c}\text { Зниження } \\
\text { матеріаломісткості } \\
\text { продуктів }\end{array}$ & $\begin{array}{c}\text { Розроблення та } \\
\text { застосування нових } \\
\text { технологій }\end{array}$ \\
\hline $\begin{array}{c}\text { Імплементація } \\
\text { процесів переробки, } \\
\text { відновлення, } \\
\text { оновлення, ремонту }\end{array}$ & $\begin{array}{c}\text { Переорієнтація на } \\
\text { діджитал- } \\
\text { альтернативи }\end{array}$ & $\begin{array}{c}\text { Перетворення } \\
\text { продуктів на } \\
\text { послуги }\end{array}$ \\
\hline $\begin{array}{c}\text { Заміна вичерпних } \\
\text { матеріалів на } \\
\text { відновлювальні }\end{array}$ & $\begin{array}{c}\text { Розроблення } \\
\text { онлайн-платформ, } \\
\text { сервісів, } \\
\text { впровадження } \\
\text { електронного } \\
\text { документообігу }\end{array}$ & $\begin{array}{c}\text { Просування ідей } \\
\text { обміну та спільного } \\
\text { використання }\end{array}$ \\
\hline
\end{tabular}

Пошук власних циркулярних рішень

Рисунок 3 - Загальнокорпоративні стратегії впровадження циркулярної економіки у діяльність підприємства 
Таблиця 3 - Проблеми впровадження циркулярної економіки в межах стратегічного управління підприємствами

\begin{tabular}{|c|c|}
\hline Група & Бар'єри \\
\hline Економічні & $\begin{array}{l}\text { - Високі початкові витрати для впровадження циркулярних бізнес-моделей та відсутність фінансової } \\
\text { спроможності й підтримки; } \\
\text { - відсутність інструментів та методів вимірювання ефективності впровадження концепції циркулярної } \\
\text { економіки на підприємстві, зокрема в довгостроковій перспективі. }\end{array}$ \\
\hline Соціальні & $\begin{array}{l}\text { - Низький рівень соціальної обізнаності щодо переваг циркулярної економіки; } \\
\text { - } \text { невизначеність реагування та попиту споживачів на нові продукти та послуги; } \\
\text { - } \text { відсутність чітких стимулів до впровадження циркулярної економіки у діяльність підприємств. }\end{array}$ \\
\hline Інституційні & $\begin{array}{l}\text { - Невизначеність у правовому регулюванні (відсутність прозорості на законодавчому рівні таких } \\
\text { понять, як екологічна відповідальність виробника, роз'яснення щодо окремих етапів рециклінгу, } \\
\text { реюзингу та рековерингу); } \\
\text { - низький рівень державної підтримки підприємств, що впроваджують безвідходне виробництво. }\end{array}$ \\
\hline Технологічні & $\begin{array}{l}\text { - Брак інформації та знань щодо технологій переробки, відновлення, спільного використання тощо; } \\
\text { - недостатність технічних потужностей. }\end{array}$ \\
\hline Ланцюг постачання & $\begin{array}{l}\text { - Відсутність налагодженої мережі циркулярного постачання; } \\
\text { - переважна спрямованість промисловості на лінійні моделі; } \\
\text { - відсутність горизонтальної та вертикальної співпраці у сфері стійкого розвитку. }\end{array}$ \\
\hline Організаційні & $\begin{array}{l}\text { - Несумісність нової стратегії з наявними (лінійними) операціями та цілями розвитку; } \\
\text { - складність стратегічного управління як процесу; } \\
\text { - відсутність ефективної системи оцінювання стратегічного управління підприємством; } \\
\text { - низький рівень знань та навичок управлінців у сфері циркулярної економіки, брак вітчизняного } \\
\text { досвіду; } \\
\text { - недовикористання інтелектуального потенціалу кадрових ресурсів, стримування ініціатив, які } \\
\text { виходять за межі вибраного курсу. }\end{array}$ \\
\hline
\end{tabular}

Джерело: сформовано авторами на основі аналізування літературного джерела [16]

у процесі стратегічного управління в умовах циркулярної економіки. Вони були згруповані за основними аспектами діяльності підприємства таким чином: економічні, соціальні, інституційні, технологічні, проблеми системи постачання та організаційні.

Отже, найбільша кількість проблем щодо впровадження циркулярної економіки в межах стратегічного управління підприємствами спостерігається в організаційному та соціальному аспектах. В організаційному аспекті це насамперед пов'язано зі складністю самої сутності стратегічного управління, опором внутрішнього середовища до змін, мінливістю зовнішнього середовища, що зазвичай випереджає швидкість впровадження довгострокових стратегічних програм. Соціальний аспект $є$ не менш важливим, оскільки ідея циркулярної економіки потребує переосмислення як виробництва, так і споживання. Всі наведені чинники значно погіршують ефективність реалізації сформованої стратегії переходу до концепції циркулярної економіки.

Стратегічні рішення щодо вирішення окреслених проблем, формування й зміцнення позицій підприємства в межах циркулярної економіки мають охоплювати такі напрями [17].

1)Робота 3 кадрами. Важливим є залучення працівників до реалізації корпоративної стратегії, забезпечення їх інформування щодо концепції циркулярної економіки й управлінських рішень щодо ії впровадження.

2)Налагодження інформаційно-аналітичного процесу, що охоплює розроблення ефективних методів аналізування важливих для підприємства чинників середовища та вжиття превентивних заходів.

3)Фінансово-економічні заходи, які спрямовані на забезпечення ресурсної ефективності підприємства, економічної стабільності, генерування додаткових доходів у межах циркулярних бізнес-моделей.

4)Правовий моніторинг, що спрямований на відстежування змін у законодавстві, особливо у сфері соціальної відповідальності підприємств, підзвітності, природокористування, державної підтримки екологічно відповідального бізнесу.

5)Активне застосування технологій, що дасть змогу розробляти принципово нові продукти та послуги 3 високим рівнем ресурсної ефективності.

6)Раціональний розподіл ресурсів, що передбачає мінімізацію рівня відходів у виробництві, вирізнення технічного та біологічного циклів, налагодження зворотної логістики.

Висновки. У результаті аналізування особливостей стратегічного управління в умовах циркулярної економіки можна стверджувати, що впровадження «циркулярних» ідей у корпоративну стратегію є необхідним кроком для створення стійкої конкурентної переваги підприємств. Такий стратегічний підхід дає змогу знизити рівень залежності корпорацій від ресурсів, які стають дедалі більш дефіцитними, тому циркулярна економіка передбачає кардинально інший підхід до ведення бізнесу, замінюючи усталену практику новими підходами, що приносять не лише прибуток, але й екологічну та соціальну користь.

Проаналізувавши підходи різних авторів до сутності циркулярної економіки, можемо підсумувати, що циркулярна економіка забезпечує поетапне відтворення, яке грунтується на принципах ресурсної ефективності та безвідходності, що закладені в самій природі. Таким чином, перехід до циркулярних моделей економіки повертає виробництво до відтворення в промислових і споживчих циклах використовуваних в 
екосистемах принципів, формування «природоподібних» технологічних систем.

Врахування ідей циркулярної економіки в корпоративній стратегії підприємства $є$ не лише сучасним трендом, але й вагомим рушієм для забезпечення довгострокової конкурентної переваги. Хоча така трансформація ставить перед управлінцями чимало вимог та викликів, вони можуть бути подолані за допомогою раціональних стратегічних управлінських рішень.

Подальше дослідження теми стратегічного управління підприємствами в умовах циркулярної економіки потребує більш ретельного розроблення моделей формування стратегій підприємства з урахуванням особливостей функціонування замкненого циклу виробництва.

\section{Список використаних джерел:}

1. Boulding, K. The economics of the coming spaceship earth. Environmental Quality in a Growing Economy: Essays from the Sixth RFF Forum. H. Jarrett. Baltimore, John Hopkins University Publ., 1966, p. 3-14.

2. McDonough, W., Braungart, M. Design for the Triple Top Line: New Tools for Sustainable Commerce. Corporate Environmental Strategy. 2002. Vol. 9. P. 251-258.

3. Stahel W.R., Reday-Mulvey G. Jobs for tomorrow: the potential for substituting manpower for energy. New York : Vantage Press, $1981,116 \mathrm{p}$

4. Ellen MacArthur Foundation. Towards the circular economy. Ellen MacArthur Foundation: UK, 2013. URL: https://www.ellenmacarthurfoundation.org/assets/downloads/publications/Ellen-MacArthur-Foundation-Towards-the-CircularEconomy-vol.1.pdf (дата звернення: 23.03.2020).

5. Hislop H., Hill J. Reinventing the wheel: A circular economy for resource security. London : Green Alliance, 2011.

6. Ellen MacArthur Foundation. Delivering the Circular Economy a Toolkit for Policymakers. Ellen MacArthur Foundation: Cowes, UK, 2015. URL: https://www.ellenmacarthurfoundation.org/assets/downloads/publications/EllenMacArthurFoundation PolicymakerToolkit.pdf (дата звернення: 27.03.2020).

7. World Resources Forum. Resources and Green Economy - WRF 2012 Beijing Meeting Report. URL: https://www.wrforum.org/ wrfpublicationspdf/wrf-2012-beijing-meeting-report (дата зверення: 30.03.2020).

8. Zhijun F., \& Nailing Y. Putting a circular economy into practice in China. Sustainability Science. 2007. Vol. 2. No. 1. P. 95-101.

9. Yuan Z., Bi J., Moriguichi Y. The circular economy: a new development strategy in China. Journal of Industrial Ecology. 2006. URL: http://onlinelibrary.wiley.com/doi/10.1162/108819806775545321/pdf (дата звернення: 03.04.2020).

10. European Commission. Moving towards a circular economy, 2014. URL: http://ec.europa.eu/environment/circular-economy (дата звернення: 05.04.2020)

11. European Commission: (EREP). Manifesto for a resource-efficient Europe. Brussels, 2012. URL: http://europa.eu/rapid/pressrelease_MEMO-12-989_en.htm (дата звернення: 11.03.2020).

12. Пахомова Н., Рихтер К., Ветрова М. Переход к циркулярной экономике и замкнутым цепям поставок как фактор устойчивого развития. Вестник Санкт-Петербургского университета. 2017. T. 33. Вып. 2. С. 244-268. DOI: 10.21638/11701/ spbu05.2017.203.

13. Сергієнко-Бердюкова Л. Передумови формування та впровадження концепції циркулярної економіки. Проблеми теорії та методологї бухгалтерського обліку, контролю і аналізу : міжнародний збірник наукових праць. 2015. Вип. 3 (33).

14. Bocken N., De Pauw I., Bakker C. Van Der Grinten B. Product design and business model strategies for a circular economy. Journal of Industrial and Production Engineering. 2016. Vol. 33. Iss. 5.

15. De los Rios I.C., Charnley F.J. Skills and capabilities for a sustainable and circular economy: The changing role of design. Journal of Cleaner Production. 2016.

16. Unlocking circular business: A framework of barriers and drivers / N. Tura, J. Hanski, T. Ahola, M. Ståhle, S. Piiparinen, P. Valkokari. Journal of Cleaner Production. 2019. Vol. 212. P. 90-98.

17. Маковецька Ю., Омельяненко Т. Формування та реалізація політики циркулярної економіки в Україні. Ефективна економіка. 2018. № 11. URL: http://www.economy.nayka.com.ua/?op=1\&z=6689 (дата звернення: 10.06.2020). DOI: $10.32702 / 2307-2105-2018.11 .86$

\section{References:}

1. Boulding, K. (1966). The economics of the coming spaceship earth. Environmental Quality in a Growing Economy: Essays from the Sixth RFF Forum. H. Jarrett. Baltimore, John Hopkins University Publ., pp. 3-14.

2. McDonough, W., Braungart, M. (2002). Design for the Triple Top Line: New Tools for Sustainable Commerce. Corporate Environmental Strategy, vol. 9, pp. 251-258.

3. Stahel, W.R., Reday-Mulvey, G. (1981). Jobs for tomorrow: the potential for substituting manpower for energy. New York, Vantage Press, $116 \mathrm{p}$

4. Ellen MacArthur Foundation (2013). Towards the circular economy. Ellen MacArthur Foundation: UK. Available at: https://www.ellenmacarthurfoundation.org/assets/downloads/publications/Ellen-MacArthur-Foundation-Towards-the-CircularEconomy-vol.1.pdf (accessed: 23.03.2020).

5. Hislop, H., Hill, J. (2011). Reinventing the wheel: A circular economy for resource security. London: Green Alliance.

6. Ellen MacArthur Foundation (2015). Delivering the Circular Economy a Toolkit for Policymakers. Ellen MacArthur Foundation:

Cowes, UK. Available at: https://www.ellenmacarthurfoundation.org/assets/downloads/publications/EllenMacArthurFoundation_ PolicymakerToolkit.pdf (accessed: 27.03.2020).

7. World Resources Forum (2012). Resources and Green Economy - WRF 2012 Beijing Meeting Report. Available at: https://www.wrforum.org/wrfpublicationspdf/wrf-2012-beijing-meeting-report (accessed: 30.03.2020).

8. Zhijun, F., \& Nailing, Y. (2007). Putting a circular economy into practice in China. Sustainability Science, 2 (1), pp. 95-101.

9. Yuan, Z., Bi, J., Moriguichi, Y. (2006). The circular economy: a new development strategy in China. Journal of Industrial Ecology. Available at: http://onlinelibrary.wiley.com/doi/10.1162/108819806775545321/ pdf (accessed: 03.04.2020).

10. European Commission (2014). Moving towards a circular economy. Available at: http://ec.europa.eu/environment/circulareconomy (accessed: 05.04.2020).

11. European Commission: (EREP) (2012). Manifesto for a resource-efficient Europe. Adopted in Brussels. Available at: http://europa.eu/rapid/press-release_MEMO-12-989_en.htm (accessed: 11.03.2020). 
12. Pakhomova, N., Richter, K., Vetrova, M. (2017). Perehod k cirkuljarnoj jekonomike i zamknutym cepjam postavok kak faktor ustojchivogo razvitija [Transition to circular economy and closed- loop supply chains as driver of sustainable development]. St Petersburg University Journal of Economic Studies, vol. 33, issue 2, pp. 244-268. DOI: 10.21638/11701/spbu05.2017.203.

13. Serhiienko-Berdiukova, L. (2015). Peredumovy formuvannia ta vprovadzhennia kontseptsii tsyrkuliarnoi ekonomiky [Prerequisites for the formation and implementation of the concept of circular economy]. Problemy teorii ta metodolohii bukhhalterskoho obliku, kontroliu i analizu : mizhnar. zbirnyk naukovykh prats, vol. 3, no. 33, pp. 327-350.

14. Bocken, N., De Pauw, I., Bakker, C. Van Der Grinten, B. (2016). Product design and business model strategies for a circular economy. Journal of Industrial and Production Engineering. Volume 33. Issue 5: Sustainable Design and Manufacturing for Circular Economy.

15. De los Rios, I.C., Charnley, F.J. (2016). Skills and capabilities for a sustainable and circular economy: The changing role of design. Journal of Cleaner Production.

16. Tura, N., Hanski, J., Ahola, T., Ståhle, M., Piiparinen, S., Valkokari, P. (2019). Unlocking circular business: A framework of barriers and drivers. Journal of Cleaner Production. Volume 212, pp. 90-98.

17. Makovetska, Y., Omelianenko, T. (2018). Formuvannia ta realizatsiia polityky tsyrkuliarnoi ekonomiky v Ukraini [Formation and implementation of the policy of the circular economy in Ukraine]. Efektyvna ekonomika, vol. 11. Available at: http://www.economy.nayka.com.ua/?op=1\&z=6689 (accessed: 12 Apr 2020). DOI: 10.32702/2307-2105-2018.11.86.

Zlotnik Marta, Melnyk Olha Lviv Polytechnic National University

\section{STRATEGIC MANAGEMENT OF CIRCULAR ECONOMY PRINCIPLES IMPLEMENTATION AT DOMESTIC ENTERPRISES}

The purpose of the study is to analyze the essence, preconditions of development, and key principles of the circular economy on the basis of current research of domestic and foreign authors and to characterize the features of strategic management of enterprises in a circular economy. The study analyzes the prerequisites for the emergence of the circular economy idea and its key principles, provides an overview of literary sources exploring the concept of a circular economy and its application at the level of strategic enterprise management. To achieve the goal of the study, the method of generalization of scientific experience and terminological analysis, analysis and synthesis, induction and deduction, system approach was used. Different approaches of scientists to the definition of the concept of "circular economy" are grouped and analyzed. On their basis, the own interpretation of this term is proposed. The characteristics of the linear type of production and circular economy are carried out, and the diagrams of their operation are shown graphically. A comparative analysis of the key principles of linear and circular economics is made. The basic strategies and business models within the circular economy are considered, the advantages of their implementation for the enterprise are characterized. Barriers to the strategic management of enterprises in the circular economy and measures to overcome them are identified. The peculiarities of strategic management in the conditions of the circular economy are defined, the individual corporate and production strategies within the circular economy are characterized, the main requirements and tasks for the implementation of circular economy ideas at the strategy level are identified. In conclusion, it was emphasized that taking into account the ideas of the circular economy in the corporate strategy of the enterprise is an important driver to ensure the long-term competitive advantage of the enterprise. Although such a transformation poses many challenges and challenges to managers, they can be overcome through sound strategic management decisions.

Key words: circular economy, linear economy, strategic enterprise management, business model, sustainable development, strategy.

JEL classification: Q01, Q50, Q57 